\title{
A Comparative Study of Consumers' Readiness for Internet Shopping in Two African Emerging Economies: Some Preliminary Findings
}

\author{
Stephen Nabareseh* \\ Christian Nedu Osakwe
}

Petr Klímek

Miloslava Chovancová

Faculty of Management and Economics, Tomas Bata University, Mostni 5139, 760 01, Zlin - Czech Republic, nabareseh@fame.utb.cz*; osakwe@fame.utb.cz; chovancova@fame.utb.cz; and klimek@fame.utb.cz

\section{Doi:10.5901/mjss.2014.v5n23p1882}

\section{Abstract}

This research seeks to empirically investigate factors that could either inhibit or facilitate consumers' readiness for Internet shopping in two highly influential countries in the African continent. In this study, a structured questionnaire-based crosssectional convenience sampling was used to elicit information from respondents in Ghana and Nigeria respectively. We have identified six cogent factors that are significantly influencing consumers' readiness for Internet shopping in both countries, these six influential factors were all subjected to hypotheses testing using non-parametric statistical methods. Based on some of our findings, we found out that demographic variables, perceived level of distrust, Internet access availability, the proliferation of social media site usage amongst the younger population all have an important role to play in the uptake of Internet shopping in both countries. We also found out that the female gender compared to the male gender in Ghana would most likely have a higher perception level of distrust in Internet shopping. It is also interesting to note that perceived level of distrust is positively correlated with the demand for the promulgation (and implementation) of Internet transactions' laws in Nigeria. By and large, we have equally pointed out some limitations of the present study and also provided some relevant future research directions given that this study is, arguably, the first of its kind in Africa to compare consumers' readiness for Internet shopping in any two African emerging economies. We are optimistic that Internet shopping offers an emerging business opportunity for retail businesses to fully take advantage of the rising digitally literate African youth populace, who constantly crave for speed of service delivery, convenience and a mutually beneficial trust based relationship.

Keywords: Africa, Consumers readiness, Ghana, Internet shopping, Nigeria

\section{Introduction}

Unarguably, shopping on the Web offers convenience to consumers as well as the ample opportunity of exploring varieties of product offerings on the Internet with the least effort (Wolfinbarger \& Gilly, 2000; Wolfinbarger \& Gilly, 2001; Li \& Zang, 2002; Harn et al., 2006; Bagdoniene \& Zemblyte, 2009). Even though Internet shopping has long been in existence in the Western world since the mid 1990s, it is yet to fully take off in the African continent.

Notwithstanding some of the infrastructure and socioeconomic challenges in Africa, it appears that the digitallysavvy African consumers, who are predominantly young Africans, are getting ready to take full advantage of the Internet as not only a medium of communication and entertainment but also as a shopping platform. For Internet shopping to thrive in African countries, the role of government as an enabler cannot be underscored (Akintola et al., 2011, Boateng et al., 2011, Aminu, 2013).

Some studies within the African context have equally shown that trust, privacy concern and demographic variables are major determinants of consumers' willingness to purchase items on the Web (Tapson, 2009, Aminu, 2013, Nabareseh \& Osakwe, 2014). Borrowing from the words of Moller \& Licker (2005), empirical works on online shopping within the African continent as a whole has received little or no academic attention. It is on this premise that this study seeks to explore consumers' readiness for Internet shopping across two economic powerhouses in the Sub-Saharan African (SSA) region, namely Ghana and Nigeria. More so, to the best of our knowledge, this research is necessitated by the fact that it is one of the first studies of its kind to compare online consumer behaviour across two countries in Africa. Nevertheless, our work is not meant to be exhaustive, given that it is a preliminary investigation into the subject matter. 
Hence, the main rationale for this study is to provide some insight into consumers' perceptions of Internet shopping in the two countries. As such, we shall identify some of the cogent factors that might be responsible for the slow uptake of Internet shopping adoption within the two countries. Clearly, some factors could either motivate or demotivate consumers from engaging in any form of online purchase.

Based on what the authors considered as the most cogent factors for Internet shopping readiness in the two countries, we have proposed to take a look at exactly six factors that are most likely influencing consumers' readiness for online purchase in both countries. These six factors are perceived level of distrust, the need for promulgation/implementation of Internet transactions laws, the proliferation of social media site usage amongst the younger population, regular power supply, growing consumers' demand for the availability of functional indigenous online stores, and Internet access availability. From the foregoing, we hereby put forth these claims (hypotheses):

$\mathrm{H} 1$ : There is a statistically significant difference between demographic variables and nationality

$\mathrm{H} 2$ : There is a statistically significant difference between Internet shopping adoption and nationality

H3: Internet access availability is positively associated with the increasing consumers' demand for the availability of functional indigenous online shopping sites in the two countries respectively

H4: Perceived level of distrust in Internet shopping is positively associated with consumers' demand for the promulgation/implementation of Internet-based transactions' laws in the two countries respectively

H5: Internet access availability is positively correlated with the demand for regular power supply in the two countries, and which in turn, will increase Internet shopping readiness

H6: The perception that the proliferation of social media site usage amongst the younger population will spur Internet shopping readiness differs based on nationality

$\mathrm{H7}$ : The female gender compared to the male gender would most likely have a higher perception level of distrust in Internet shopping in the two countries respectively

H8: The male gender in each of the two countries is more likely to demand for the promulgation/implementation of Internet transactions' laws compared to the female gender

\section{Some Stylized Facts on Internet Shopping Readiness in Africa with Emphasis on Ghana and Nigeria}

Indisputably, the African continent lags (see figure 1) behind the rest of the world in terms of Internet diffusion, and in particular, Internet shopping. The Internet penetration in Africa is currently estimated at 16.3 percent, it is very worrisome that only about 11.1 percent of households in Africa can actually boast of having Internet access in their homes. Also, while active mobile-broadband subscription is estimated to be 19 percent in 2014, the penetration of fixed (wired)broadband subscription is currently put at 0.4 percent (ITU, 2014).

Figure 1: Households with Internet Access, by Global Region and Development (Per 100 Inhabitants)

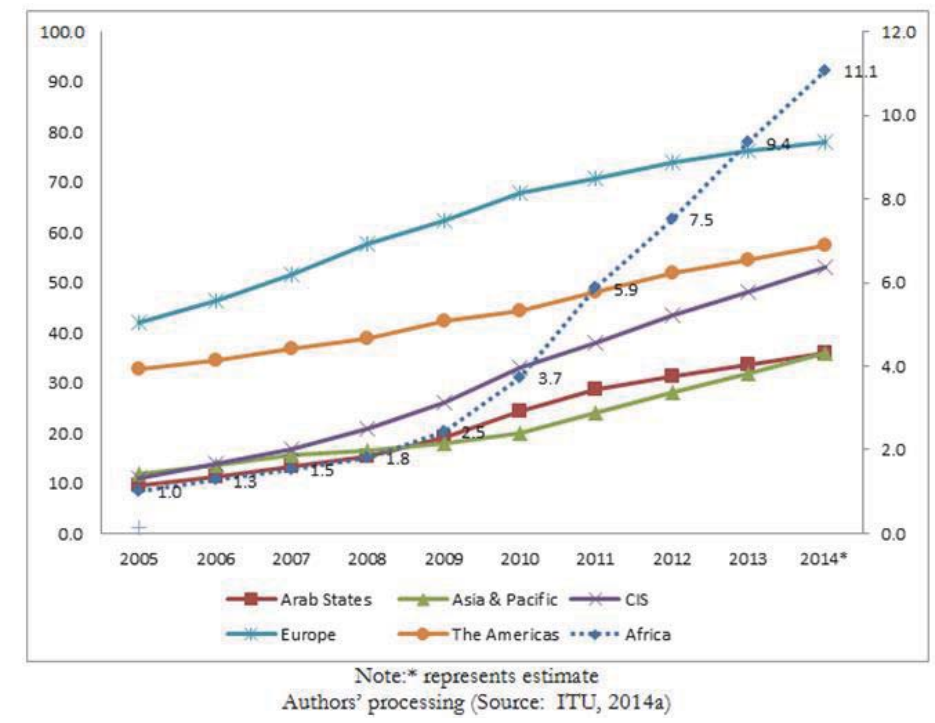

Understandably, the African regional ICT development index score of 2.0 (see figure 2) is by far the lowest amongst all 
the regions in the world. The ICT development index, which is a composite index, consists of three-stage model-ICT readiness, ICT intensity, and ICT impact (ITU, 2013). The ICT index provides a good yardstick for measuring the level of digitization in the global economy. Arguably, the ICT development index score could serve as a proxy for Internet shopping readiness in any region or country. Moreover, on the average, fixed-broadband price in the African region constitutes about 64.3 percent of the region's Gross National Income per capita (GNI p.c.), thereby making Internet access within the region to be the least reasonably priced amongst other regions in the world (ITU, 2013). Even though a majority of Africans access the Internet using their mobile devices, mobile-broadband subscription fees in the region still remains the most expensive in any part of the globe (ITU, 2013).

Figure 2: The African Regional ICT Development Index Score of 2012 in Comparison with Global, Regional, and Developing/Developed Country Averages

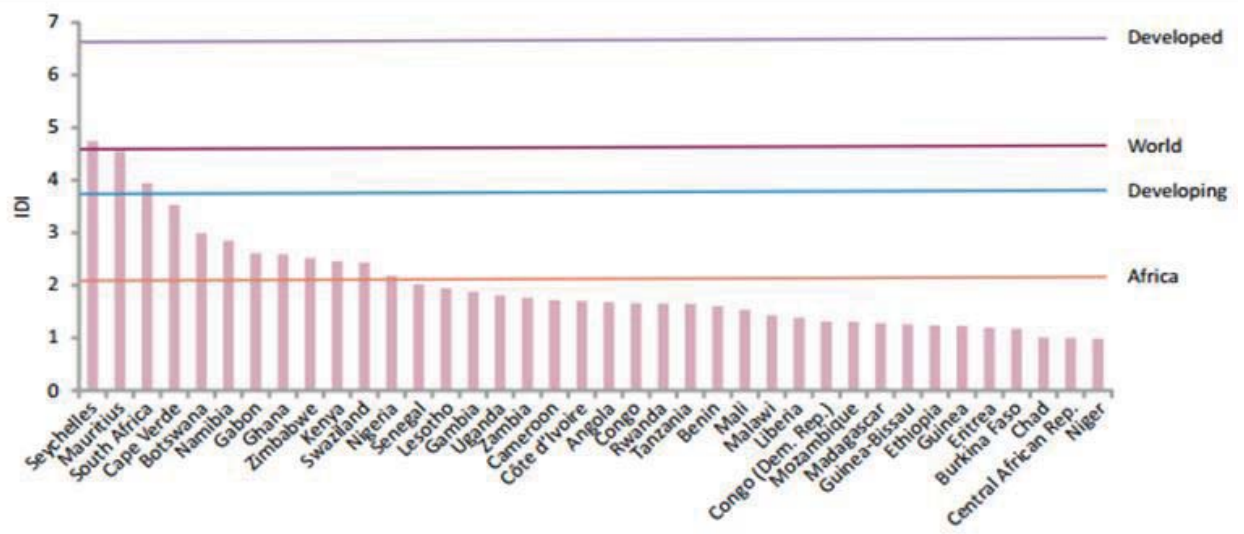

Source: ITU, 2013

Similarly, the most populous country in Africa, Nigeria, has an Internet penetration of 37.59 percent, while the Internet penetration in Ghana with a population of slightly over 26 million people is estimated to be 19.56 percent (Internet Live Stats, 2014). Apparently, the low Internet penetration rate in the African continent is a major disincentive to the adoption of Internet shopping by its teeming population. It is almost a truism in the developing economies, and in particular Ghana and Nigeria, that the slow uptake of Internet shopping is fundamentally as a result of low Internet penetration in these economies.

Aside the low Internet penetration in these two countries, there is a dearth of critical infrastructure such as good road networks, railway lines, telecommunication, postal system, and power supply. The bedrock of any ICT-driven economy as it is in the western world is built on having the right critical infrastructure on ground to power an economy, and which ultimately spur business innovations and creativity. Going by global rankings by some eminent institutions as well as data from the World Bank, it shows that at a macro level, Internet shopping readiness is still a long walk for both countries given the level of their preparedness to achieving a digital economy. Aside the aforementioned factors influencing consumers' readiness for Internet shopping in both Ghana and Nigeria respectively, we have put together some other vital determinants of Internet shopping readiness in the two emerging economies (see table 1).

Table 1: Internet Shopping Readiness in Ghana and Nigeria: Selected Macro-Level Influential Indicators

\begin{tabular}{lccl}
\hline Indicator & Ghana & Nigeria & Source \\
GNI per capita 2012, PPP US\$ & $1940(2012)$ & $2420(2012)$ & UNICEF, 2014 \\
Internet Contribution to GDP (iGDP) & $1.1(2013)$ & $0.8(2013)$ & McKinsey\& Company, 2013 \\
Population below international poverty line of US\$1.25 per day (\%) & $28.6(2007-2011)$ & $54.4(2007-2011)$ & UNICEF, 2014 \\
Urban population growth (annual \%) & $3.4(2012)$ & $4(2012)$ & World Bank WDI, 2014 \\
Total adult literacy rate (\%) & $71.5(2008-2012)$ & $51.1(2008-2012)$ & UNICEF, 2014 \\
Youth literacy rate (\%) & $85.7(2010)$ & $66.4(2008)$ & UNESCO Institute for Statistics, 2013 \\
Households with a computer (\%) & $13.8(2012)$ & $9.3(2011)$ & ITU, 2014b \\
Households with Internet access (\%) & $11(2012)$ & $6.1(2010)$ & ITU, 2014b \\
Fixed-broadband price (PPP\$) & $51.6(2012)$ & $68(2012)$ & ITU, 2013 \\
Mobile-broadband prepaid handset-based pricing (500MB) - as a \% & $9(2012)$ & $13(2012)$ & ITU, 2013 \\
of GNI per capita & & & \\
\hline
\end{tabular}




\begin{tabular}{|c|c|c|c|}
\hline Indicator & Ghana & Nigeria & Source \\
\hline Access to electricity (\% of population) & $72(2011)$ & 48(2011) & World Bank WDI, 2014 \\
\hline Number of electrical outages in a typical month & $9.5(2007)$ & $25.2(2007)$ & World Bank WDI, 2014 \\
\hline Secure Internet servers (per 1 million people) & 2.63 (2013) & $1.68(2013)$ & World Bank WDI, 2014 \\
\hline Mobile cellular subscriptions (per 100 people) & $100.99(2012)$ & $66.8(2012)$ & World Bank WDI, 2014 \\
\hline $\begin{array}{l}\text { Logistics performance index: Ability to track and trace consignments } \\
\text { (1=low to } 5=\text { high) }\end{array}$ & $2.31(2012)$ & $2.35(2012)$ & World Bank WDI, 2014 \\
\hline $\begin{array}{l}\text { Logistics performance index: Quality of trade and transport-related } \\
\text { infrastructure (1=low to 5=high) }\end{array}$ & $2.05(2012)$ & $2.27(2012)$ & World Bank WDI, 2014 \\
\hline African Retail Development Index SSA Ranking & $6(2014)$ & $2(2014)$ & A.T. Kearney, 2014 \\
\hline Social media penetration rate (\%) - proxied by Facebook subscribers & $6.4(2012)$ & $3.9(2012)$ & Internet World Stats, 2014 \\
\hline Firms having their own Web site (\%) & $8.2(2007)$ & $9.7(2007)$ & World Bank WDI, 2014 \\
\hline ICT Development Index Global Ranking & $113(2012)$ & $122(2012)$ & ITU, 2013 \\
\hline Web Index Global Ranking & $55(2013)$ & $67(2013)$ & World Wide Web Foundation,20 13 \\
\hline The Networked Readiness Index Global Ranking & 95 (2013) & $113(2013)$ & WEF, 2013 \\
\hline Rule of Law Index Global Ranking & $37(2014)$ & $93(2014)$ & The World Justice Project, 2014 \\
\hline Interpersonal Trust Index (where below $100=$ less trust) & $17.4(2007)$ & $29.8(2005)$ & ASEP/JDS, 2014 \\
\hline
\end{tabular}
Note: Year of data availability is in brackets

Source: Authors' compilations from verifiable sources

\section{Research Methodology}

Given the nature of this work as largely an exploratory research, we have opted to make use of a cross-sectional research design. A structured questionnaire consisting of demographic variables and Likert item questions was sent out to Ghanaian and Nigerians respondents to fill in both electronic and hard copy formats by means of a convenience sampling method. For the hard copy questionnaire, we have used an unpaid proxy to distribute the questionnaires to respondents based in the two countries. It is important to state that sample respondents were asked to give their opinions based on six Likert items which were anchored on a 5-point scale ranging from completely disagree to completely agree.

Taking into cognizance the cutoff time for the study, we were only able to get a feedback from 202 sample respondents. From a total of 202 responses, only 197 questionnaires were found to be usable for the study owing to the omission of some vital information from five of our sample respondents. For the purpose of this work, we have used Chi Square, Mann Whitney U and Spearman Rank Correlation to either confirm or refute our highlighted hypotheses.

\section{Research Findings and Discussion}

Table 2: Socio-Demographic Variables of Sample Respondents

\begin{tabular}{c|c|c|c}
\hline & \multicolumn{3}{|c}{ Sample Size, $n=197$} \\
\hline Socio-demographic variables & Ghanaian (\%) & Nigerian (\%) & Results of the Chi Square Test \\
\hline Gender & 65.3 & 50.8 & \multirow{2}{*}{$\left(\mathrm{X}^{2}=3.978, \mathrm{df}=1 ; \mathrm{p}=0.046\right)^{\star}$} \\
Female & 34.7 & 49.2 & \\
Male & 28 & 19.7 & \\
\hline Age Group & 37.3 & 57.3 & $\left(\mathrm{X}^{2}=9.731, \mathrm{df}=1 ; \mathrm{p}=0.021\right)^{\star}$ \\
Under 26 & 24 & 19.7 & \\
26-35 & 10.7 & 3.3 & \\
36-45 & & & \\
Over 45 & 10.7 & 18.9 & \\
Level of Education & 32 & 16.4 & $\left(X^{2}=17.023, \mathrm{df}=1 ; p=0.001\right)^{\star *}$ \\
High School & 32 & 53.2 & \\
Undergraduate & 25.3 & 11.5 & \\
Graduate & 29.3 & 19.7 & \\
Post Graduate & 13.4 & 16.4 & $\left(X^{2}=4.873, \mathrm{df}=1 ; p=0.301\right)$ \\
Monthly Income (US\$) & 17.3 & 21.3 & \\
Under 150 & 17.3 & 11.5 & \\
150 - 350 & 22.7 & 31.1 & \\
351 - 700 & &
\end{tabular}




\begin{tabular}{c|c|c|c}
\hline Primary Internet Access Point & 5.3 & 8.2 & \\
Cybercafe & 20 & 6.6 & \\
School & 26.7 & 32.8 & $\left(\mathrm{X}^{2}=12.898, \mathrm{df}=1 ; \mathrm{p}=0.012\right)^{\star}$ \\
Workplace & 30.7 & 43.4 & \\
Mobile Device & 17.3 & 9 & \\
Home PC & 33.3 & 59 & \multirow{2}{*}{$\left(\mathrm{X}^{2}=12.258, \mathrm{df}=1 ; \mathrm{p}=0.000\right)^{\star \star}$} \\
\hline Internet Shopping Adoption & 66.7 & 41 & $\mathrm{~N} / \mathrm{A}$ \\
Adopter & 38.1 & 61.9 & \\
Non-adopter & Nationality &
\end{tabular}

Note the asterisks $\left({ }^{\star *}, *\right)$ represent statistical significance at the 0.01 and 0.05 levels respectively

\section{Source: Authors' Processing Extracted from the SPPS Software}

As depicted in table 2 (see above), nearly 62 percent of sample respondents were Nigerians while Ghanaian respondents constituted exactly 38.1 percent of survey respondents. The predominant age group in the survey constituted of those aged between 26-35 in both countries. In terms of gender, the majority of respondents in the two countries are females. Similarly, the majority of respondents in both countries are university (or polytechnic) graduates.

However, while a majority of Ghanains in our survey has a monthly income of less than 150 USD, the monthly income for majority of Nigeria respondents is well over 1000 USD. Moreover, there were significant differences between most of the demographic variables and nationality, thus, partially supporting hypothesis 1 (kindly see the fourth column in table 2 for details).

Also, a majority of the Ghanaian respondents access the Internet using their mobile devices while only about 17.3 percent of our Ghanain respondents access the Internet using home PCs. A similar trend repeated itself amongst our Nigerian respondents. In Nigeria, only about 9 percent of the surveyed respondents have Internet connections with home PCs; a majority of Nigerians in the survey make use of mobile broadband access. In a way, our findings provide ample evidence that fixed broadband access penetration in both countries is extremely low. Thus, justifying various leading indicators of ICT development index used by reputable global organizations to rank countries and regions based on their preparedness towards a digitized and an Internet-based economy.

More so, taking a look at the fourth column in table 2, we can confirm that our second hypothesis was supported given that the adoption of Internet Shopping differs based on nationality. The stated hypothesis $(\mathrm{H} 2)$ is statistically significant at the 0.01 level. We can infer that Nigerian respondents are more likely to use the Internet for their shoppings tasks compared to Ghanaians in our survey. Owing to the small sample size and choice of non-probability sampling method, we are very careful to state that it may appear that Nigerians are more eager to adopt Internet shopping compared to their Ghanaian counterparts.

Table 3: Some Hypotheses Outcomes using the Spearman Rank Correlation Test

\begin{tabular}{l|c|c|c}
\hline Hypothesis & Ghana & Nigeria & Outcome \\
\hline $\begin{array}{l}\text { H3: Internet access availability is positively correlated with the demand for } \\
\text { functional indigenous online shopping sites }\end{array}$ & $\begin{array}{c}r(73)=0.281^{*} \\
p=0.015\end{array}$ & $\begin{array}{c}r(120)= \\
0.264^{* *} \\
p=0.003\end{array}$ & Supported \\
\hline $\begin{array}{l}\text { H4: Perceived level of distrust in Internet shopping is positively correlated } \\
\text { with the demand for the promulgation/implementation of Internet } \\
\text { transactions' laws }\end{array}$ & $\begin{array}{c}\text { Not } \\
\text { Significant }\end{array}$ & $\begin{array}{c}r(120)=0.385^{\star *} \\
p=0.000\end{array}$ & $\begin{array}{c}\text { Partially } \\
\text { Supported }\end{array}$ \\
\hline $\begin{array}{l}\mathrm{H} 5 \text { : Internet access availability is positively correlated with the demand for } \\
\text { regular power supply, and which in turn, will increase Internet shopping } \\
\text { readiness }\end{array}$ & $\begin{array}{c}\text { Not } \\
\text { Significant }\end{array}$ & $\begin{array}{c}r(120)=0.290^{\star *} \\
p=0.001\end{array}$ & $\begin{array}{c}\text { Partially } \\
\text { Supported }\end{array}$ \\
\hline
\end{tabular}

The asterisk $\left.{ }^{* *}\right)$ represents statistical significance at the 0.01 level.

Source: Authors' Processing Extracted from the SPPS Software

Furthermore, a look at table 3 (see above) shows that Internet access availability is positively correlated to the growing consumers' demand for the availability of functional indigenous online shopping sites in the two countries. This outcome is statistically significant at both 0.05 and 0.01 levels for Ghana and Nigeria respectively. Thus, confirming the third hypothesis $(\mathrm{H} 3)$. 
As shown in table 3 , the fourth hypothesis $(\mathrm{H} 4)$ is partially supported given that perceived level of distrust in Internet shopping and the need for promulgation with the implementation of Internet transactions' laws is positively correlated as well as statistically significant at the 0.01 level only in the case of Nigeria. Taking the two samples together, perceived level of distrust and the need for the regulation of Internet transactions are positively correlated. This is statistically significant at the 0.01 level $(r(195)=0.234 ; p=0.001)$. It is plausible to state that from our findings, the level of distrust in Internet shopping within the two emerging economies is quite high. Hence, consumers would feel safer to transact online when there are effective regulations in place. Unarguably, this finding is not only typical of the sample respondents, but also, it is applicable to all rational consumers.

Similarly, the fifth hypothesis (H5) is partially supported (refer to table 3). We are careful to state that Internet access availability and regular power supply are both positively associated in the case of Nigeria. Perhaps, Nigerians believe that having an uninterruptible power supply could motivate people to have Internet access, and which in turn, will hasten Internet shopping readiness.

In the case of Ghana, we do not have any form of statistical evidence to support our claims. Besides, due to the fact that Ghanaians enjoy more regular power supply than their Nigerian counterparts, power supply might not be so strong a predictor of Internet shopping readiness (proxied by Internet access availability) in Ghana.

Table 4: Some Hypotheses Outcomes using the Mann Whitney U Test

\begin{tabular}{|c|c|c|c|}
\hline Hypothesis & Ghana & Nigeria & Outcome \\
\hline $\begin{array}{l}\text { H6: The perception that the proliferation of social media site } \\
\text { usage amongst the younger population will spur Internet shopping } \\
\text { readiness differs across both countries }\end{array}$ & \multicolumn{2}{|c|}{$\begin{array}{l}U=3725 ; p=0.023 \\
\text { Mean rank of } 87.67 \text { and } 105.97 \text { for Ghana } \\
\text { and Nigeria respectively }\end{array}$} & Supported \\
\hline $\begin{array}{l}\text { H7: The female gender compared to the male gender would most } \\
\text { likely have a higher perception level of distrust in Internet } \\
\text { shopping in the two countries respectively }\end{array}$ & $\begin{array}{c}\mathrm{U}=454.4 ; \mathrm{p}=0.024 ; \\
\text { Female mean rank = } \\
41.72 ; \\
\text { Male mean rank }=30.98\end{array}$ & $\begin{array}{c}\text { Not } \\
\text { Significant }\end{array}$ & $\begin{array}{l}\text { Partially } \\
\text { Supported }\end{array}$ \\
\hline $\begin{array}{l}\text { H8: The male gender in each of the two countries is more likely to } \\
\text { demand for the promulgation/implementation of Internet } \\
\text { transactions' laws compared to the female gender }\end{array}$ & $\begin{array}{c}\mathrm{U}=373.5 ; p=0.001 ; \\
\text { Female mean rank }= \\
32.62 ; \\
\text { Male mean rank }=48.13\end{array}$ & $\begin{array}{c}\text { Not } \\
\text { Significant }\end{array}$ & $\begin{array}{l}\text { Partially } \\
\text { Supported }\end{array}$ \\
\hline
\end{tabular}

\section{Source: Authors' Processing Extracted from the SPPS Software}

As shown in table 4 (see above), $\mathrm{H} 6$ is equally supported. There is evidence to show that the proliferation of online social media site usage by the younger population could possibly fuel Internet shopping readiness in the two countries, though, with some differences based on respondents' nationality perceptions.

Our findings show that Nigerians within the sample are much more positive (mean rank of 105.97) compared to Ghanains (mean rank of 87.67) that the trend in online social media site usage by the younger population will hasten Internet shopping readiness. Moreover, both $\mathrm{H} 7$ and $\mathrm{H} 8$ are partially supported, showing statistical evidence for the case of Ghanaian respondents only.

Hence, we are very careful to state that females (mean rank of 41.72) compared to males (mean rank of 30.98) are more likely to have a higher perception level of distrust in Internet shopping in Ghana. Perhaps, due to the small sample size of our survey, we were unable to find any statistical evidence amongst the Nigerian respondents. So it is equally possible that a similar trend might have repeated itself between male and female Nigerians perceptions of distrust in Internet shopping but there is no statistical evidence to support such in this study. It is also possible that both males and females are very much suspicious of Internet shopping in Nigeria, hence, the resultant outcome of our survey.

However, it appears that male respondents (mean rank of 48.13) from Ghana are more desirous for the swift regulation of Internet transactions compared to their Ghanain female counterparts (mean rank of 32.62), our finding is statistically significant at the 0.01 level.

On the contrary, we failed to provide any statistically significant difference between the two genders in Nigeria. It may be that both males and females in Nigeria are very much keen to see the Nigerian government provide an effective and robust legal support system for all Internet-enabled transactions. Hence, no significant difference exists in both genders demand for the promulgation with the implementation of Internet transactions' laws in Nigeria. 


\section{Conclusions, Implications, and Future Research}

Based on our preliminary findings, we are of the opinion that consumers' readiness for Internet shopping in the two countries presents some business opportunities for local retail businesses to fully exploit given the market size of both economies. Nevertheless, the realization of such opportunities requires governmental support most especially in the areas of Internet transactions legislation and provision of critical infrastructure such as regular power supply, telecommunication, transportation networks, and an efficient postal system. Indubitably, without widespread Internet penetration in both countries, consumers' readiness for Internet shopping will always remain a mirage. Hence, there is a need by the governments of these countries to create an enabling milieu that could foster not only the deployment of Internet connectivity across the length and breadth of the two countries but also the affordability of Internet access.

In addition, local retail businesses should seize the opportunities inherent in these economies by joining hands with other stakeholders in the electronic commerce landscape through the provision of secured with customer-friendly online shopping websites. This has the possibility of dousing the perception of distrust amongst consumers in the context of Internet shopping. Internet shopping hinges on trust and creating the right experiences for online consumers, as such online organisations in these two countries must build trust in their businesses, since this would motivate consumers to patronize their services.

Looking ahead, we opine that as the majority of the younger population in these two countries utilize social media sites, it is most likely that younger consumers would adopt Internet shopping not only based on utilitarian with hedonistic motivation but also, the need to set themselves apart from the older generation. By and large, even though consumers' readiness for Internet shopping in both Ghana and Nigeria is still a long way to go owing to some of the highlighted factors cited in this paper, we are very much optimistic about the future of Internet shopping in Sub-Saharan Africa, and in particular, Ghana and Nigeria.

On a final note, we would like to reiterate that our work presents preliminary findings of consumers' readiness for Internet shopping in the two countries, and as such our work might not fully reflect the current happenings regarding Internet shopping readiness in both countries. More so, we have used a non-probability sampling technique. It is our hope that some researchers might take a cursory look at our findings and equally investigate it further with a larger sample size of the two countries. There is equally room for researchers to empirically investigate the impact of culture on consumers' readiness for Internet shopping in the two countries. A similar study might look at small and medium-sized retail business readiness for the deployment of online shops in each of the two countries. Also, some researchers could look at consumers' attitudes towards electronic commerce from a sub-regional perspective in SSA given that electronic commerce has the possibilities of opening up socioeconomic opportunities for SSA's teeming population. We have presented a gamut of new research directions, it is our hope that these highlighted areas would be explored by researchers in the nearby future.

In all, we are very much optimistic that the African electronic marketplace is on the rise, and Internet shopping offers an emerging business opportunity for both indigenous and foreign retail businesses to fully take advantage of the rising digitally literate African youth populace, who constantly crave for speed of service delivery, convenience and a mutually beneficial trust based relationship.

\section{Acknowledgement}

This work was in part supported by the Internal Grant Agency TBU Zlin Project IGA/ FaME/2014/007.

\section{References}

A.T. Kearney (2014). The 2014 African Retail Development Index: Seizing Africa's Retail Opportunities. Accessed 22-05-2014. Available at: http://www.atkearney.com/documents/10192/4371960/Seizing+Africas+Retail+Opportunities.pdf/730ba912-da69-4e09-9b5d69b063a3f139

Akintola, K.G., Akinyede R.O. and Agbonifo, C.O. (2011). APPRAISING NIGERIA READINESS FOR ECOMMERCE TOWARDS: ACHIEVING VISION 20: 2020. IRPAS, 9 (2), pp.330-340.

Aminu, S.A. (2013). Challenges Militating against Adoption of Online Shopping in Retail Industry in Nigeria. Journal of Marketing Management, 1 (1), pp. 23-33.

ASEP/JDS (2014). World Map of Interpersonal Trust. Accessed 11-06-2014. Available at: http://www.jdsurvey.net/jds/jdsurveyMaps.jsp? Idioma $=\mid \&$ SeccionTexto=0404\&NOID=104

Bagdoniene, L. and Zemblyte, J. (2009). Online Shopping Motivation Factors And Their Effect On Lithuanian Consumers. Economics \& Management: 14, pp. 367-374. 
Boateng, R., Heeks, R., Molla, A., and Hinson, R. (2011). Advancing E-commerce beyond readiness in a developing country: Experiences of Ghanaian firms. Journal of Electronic Commerce in Organizations, 9 (1), pp. 1-16.

Harn, A.C. P., Khatib, A. and Ismail, H. B. (2006). E-Commerce: A Study on Online Shopping in Malaysia. J. Soc. Sci., 13 (3): $231-242$.

Internet Live Stats (2014). Internet Users by Country. Accessed 10-06-2014. Available at: http://www.internetlivestats.com/internetusers-by-countryl

Internet World Stats (2014). Usage and Population Statistics: Africa. Accessed 14-06-2014. http://www.internetworldstats.com/ africa.htm\#ng

ITU (2013). Measuring The Information Society. Accessed 11-6-2014: Available at: http://www.itu.int/en/ITU-D/Statistics/Documents/ publications/mis2013/MIS2013_without_Annex_4.pdf

ITU (2014a). Key ICT indicators for developed and developing countries and the world (totals and penetration rates). ITU World Telecommunication/ICT Indicators Database. Accessed 10-06-2014: http://www.itu.int/en/ITU-D/Statistics/Pages/stat/default.aspx

ITU (2014b). Core indicators on access to, and use of, ICT by households and individuals, latest available data (2008-2012). ITU World Telecommunication/ICT Indicators Database. Accessed 10-06-2014: http://www.itu.int/en/ITU-D/Statistics/Pages/stat/default.aspx

Li, N. and Zhang, P. (2002). Consumer Online Shopping Attitudes and Behavior: An Assessment of Research. Conference Proceedings of the Eighth Americas Conference on Information Systems, pp 508-517.

McKinsey \& Company (2013). Lions go digital: The Internet's transformative potential in Africa. Accessed 13-06-2014. Available at: http://www.mckinsey.com/insights/high_tech_telecoms_internet/lions_go_digital_the_internets_transformative_potential_in_africa

Molla A and Licker P.S (2005). eCommerce adoption in developing countries: a model and instrument. Information Management 42 (6), pp. 877-899.

Nabareseh, S. and Osakwe, N. C. (2014). Can Business-to-Consumer Electronic Commerce Be a Game-Changer in Anglophone West African Countries? Insights from Secondary Data and Consumers' Perspectives. World Applied Sciences Journal 30 (11): pp. $1515-1525$.

Tapson,M. J. (2009). Demographical Diversity Influence on Online Shopping Orientation and Propensity to Buy Online. Master's Thesis, Rhodes University, South Africa. Accessed 10-06-2014: http://eprints.ru.ac.za/2405/1/TAPSON-MA-TR10-151.pdf

The World Justice Project (2014). Rule of Law Index; Global Rankings. [Online]. Available: http://worldjusticeproject.org/sites/ default/files/files/wjp_rule_of_law_index_2014_report.pdf [Accessed 21-05-2014].

UNESCO Institute for Statistics (2013). Adult and Youth Literacy: National, regional and global trends, 1985-2015. UIS Information Paper. Accessed 09-06-2014. Available at: http://www.uis.unesco.org/Education/Documents/literacy-statistics-trends-19852015.pdf

UNICEF (2014). Country Statistics. Accessed 10-06-2014: http://www.unicef.org/infobycountry

WEF (2013). The Global Information Technology Report 2013: Growth and Jobs in a Hyperconnected World. Accessed 11-06-2014: http://www3.weforum.org/docs/WEF_GITR_Report_2013.pdf

Wolfinbarger, M. and Gilly, M. (2000). Consumer Motivations for Online Shopping. Proceedings of the Sixth Americas Conference on Information Systems (AMCIS), pp. 1362-1366.

Wolfinbarger, M. and Gilly, M. C. (2001). Shopping Online for Freedom, Control and Fun. California Management Review, 43 (2) pp. $34-$ 55.

World Wide Web Foundation (2013). Web Index: The 203 Rankings. Accessed 11-06-2014. Available at: https://thewebindex.org /data/index/ 